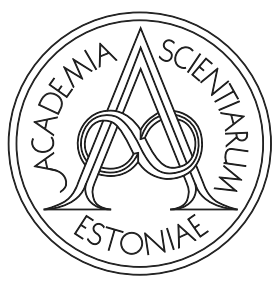

Proceedings of the Estonian Academy of Sciences,

$2021,70,4,422-428$

https://doi.org/10.3176/proc.2021.4.08

Available online at www.eap.ee/proceedings

MANUFACTURING

ENGINEERING

\title{
Simulation based feasibility analysis of autonomously movable robot arm
}

\author{
Kristo Vaher ${ }^{\mathrm{a} *}$, Kashif Mahmood ${ }^{\mathrm{b}}$, Tauno Otto ${ }^{\mathrm{b}}$ and Jüri Riives ${ }^{\mathrm{b}}$ \\ a TTK University of Applied Sciences, Pärnu mnt 62, 10135 Tallinn, Estonia \\ b Tallinn University of Technology, Ehitajate tee 5, 19086 Tallinn, Estonia
}

Received 15 June 2021, accepted 14 July 2021, available online 2 November 2021

(C) 2021 Authors. This is an Open Access article distributed under the terms and conditions of the Creative Commons AttributionNonCommercial 4.0 International License (http://creativecommons.org/licenses/by-nc/4.0/).

\begin{abstract}
The use of industrial robots in production is rapidly growing. However, the vast use of industrial robots and implementation of new manufacturing technologies are mostly adopted by large industrial companies. It is due to the nature of the production volume, as robots perform a fair amount of the same work in one specific position in the production process. In smaller companies where robots do not often have sufficient workload in a single specific workplace, the process of robotization has not been so successful. SMEs (small and medium-sized enterprises) need a solution how the robot can be moved from one workplace to another in order to utilize the resources, such as a robot arm, efficiently. This paper aims to analyse the feasibility of the usage of a robotic arm (a collaborative robot) to serve more than a single production cell intermittently. Production machines are located at a particular distance from each other and the movement of the robotic arm between the machines is carried out autonomously with the help of an autonomous mobile robot. Simulation and 3D visualization were used to conduct and analyse two different scenarios of an autonomously moving robot. Utilization of production equipment was considered as a key performance indicator.
\end{abstract}

Key words: Industry 4.0, industrial robots, cobots, smart machines, machine vision.

\section{INTRODUCTION}

In manufacturing industry automation via robots for different applications is inevitable. The recent evolvement of the Industry 4.0 concept and new industrial communication technologies such as the Internet of Things in manufacturing have led the automation to the autonomous level.

The applications of industrial robots (industrial robots are automated, programmable and capable of movement on three or more axes) are observed mainly for repetitive and high-precision tasks or monotonous tasks demanding physical effort. The development of collaborative robots ensures safe working conditions for human workers and allows human workers to confidently share the workspace with robots [1]. It means there is omission of fences for industrial robots and utilization of space can be increased on the factory floor. The new industrial robots can have an ability to move freely and execute several complex activities like humans do [2]. Furthermore, free movement of cobots (collaborative robots) on the shop floor enables better utilization of the surface area in production as well as enhanced usage of resources, possible reduction in costs for automated cells, timely and easier access to the process machines, and lower downtime. It may encourage smaller companies to implement robotic solutions [3]. One of the possibilities to autonomously move a robotic arm among several machines is to

\footnotetext{
${ }^{*}$ Corresponding author, vaher.kristo@gmail.com
} 
use the Autonomous Mobile Robot (AMR) platform and mount a robot arm on the AMR. Calibration of the robot arm's position relative to the workstation was solved in our previous article [4].

Analysing a change or testing a solution can be performed digitally by creating a similar-scale virtual environment and simulating it. In the digital manufacturing context, the use of simulation tools allows for the performance evaluation of manufacturing systems and production cells with the help of certain performance indicators $[5,6]$. In this case, there is no need to acquire physical resources and the changes can be validated through a digital manufacturing approach [7].

Relevant literature has analysed the need for mobility generated by industrial robots $[8,4]$ and identified possible solutions for it. The solutions for moving a robot manually by a human or automatically by a mobile robot were evaluated in [8]. The automatic positioning accuracy of the robot arm moved by the mobile robot was analysed using machine vision [4]. Interesting approach was suggested [9] for replacement of manual work by hybrid production by means of autonomous dual arm robots, enhancing operator's working conditions and maintaining the same production levels. Nielsen et al. showed [10] that mobile robot arms can continuously perform meaningful industrial tasks such as the so-called bartender concept in cloud manufacturing (CMfg).

This article evaluates the efficiency and cost-effectiveness of a solution where the robot arm is moved by the mobile robot. A 3D simulation software was used for this purpose. The aim of the simulation was to analyse different production scenarios of an autonomously moving robot and to compare them with a situation where people perform the same work.

This research was carried out in the framework of the development of semi-industrial Industry 4.0 Lab, involving a robotised production line, 3D printing stations and an automatic storage system (see Fig. 1).

\section{DESCRIPTION OF SIMULATION}

In this simulation (Fig. 2), the Robot Arm (RA) was moved from Work Position 1 (WP 1) to Work Position 2 (WP 2) by the Mobile Robot (MR). Upon arrival at its work position, the robot arm positioned itself relative

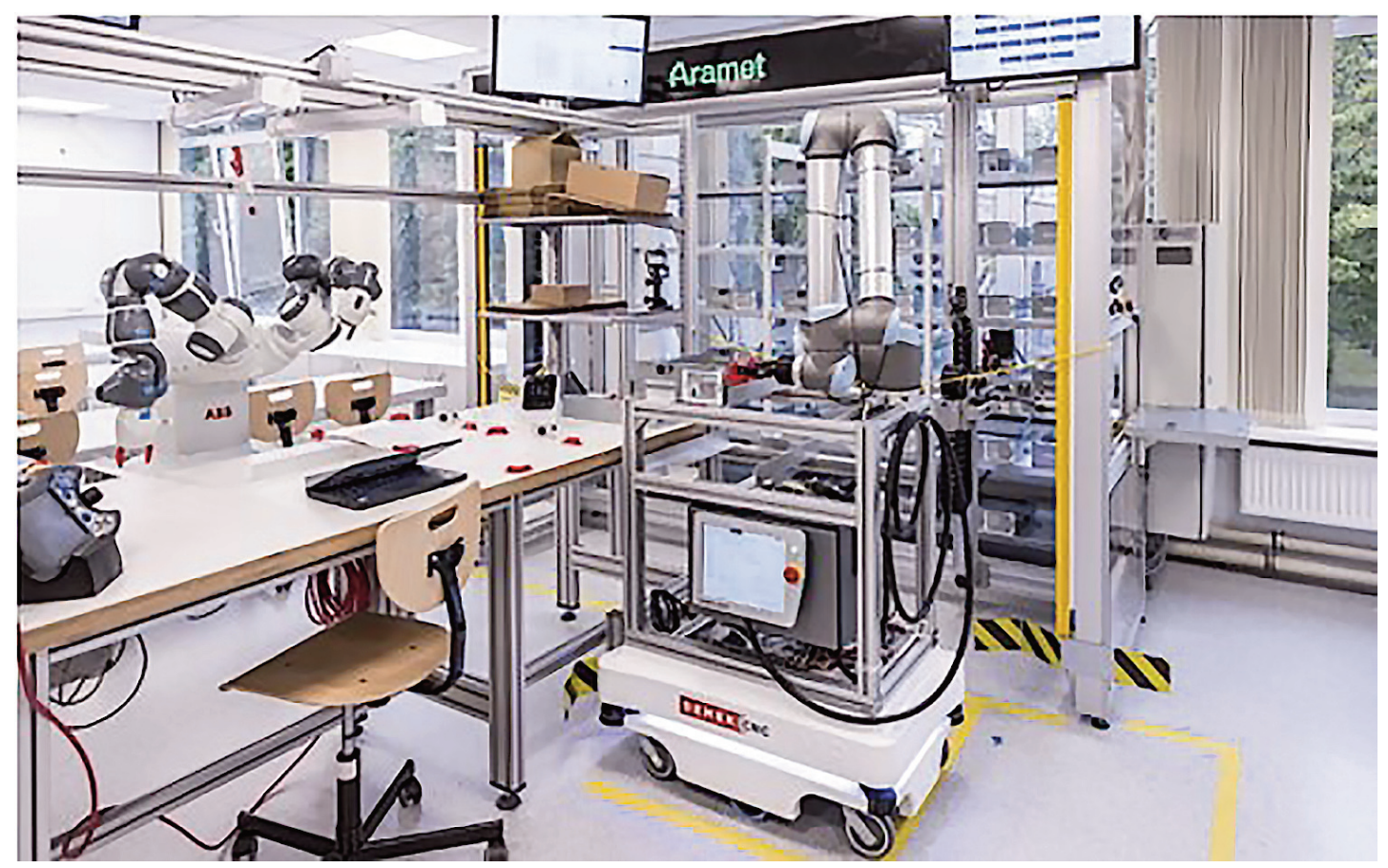

Fig. 1. Semi-industrial Industry 4.0 Lab with autonomous cobot platform. 


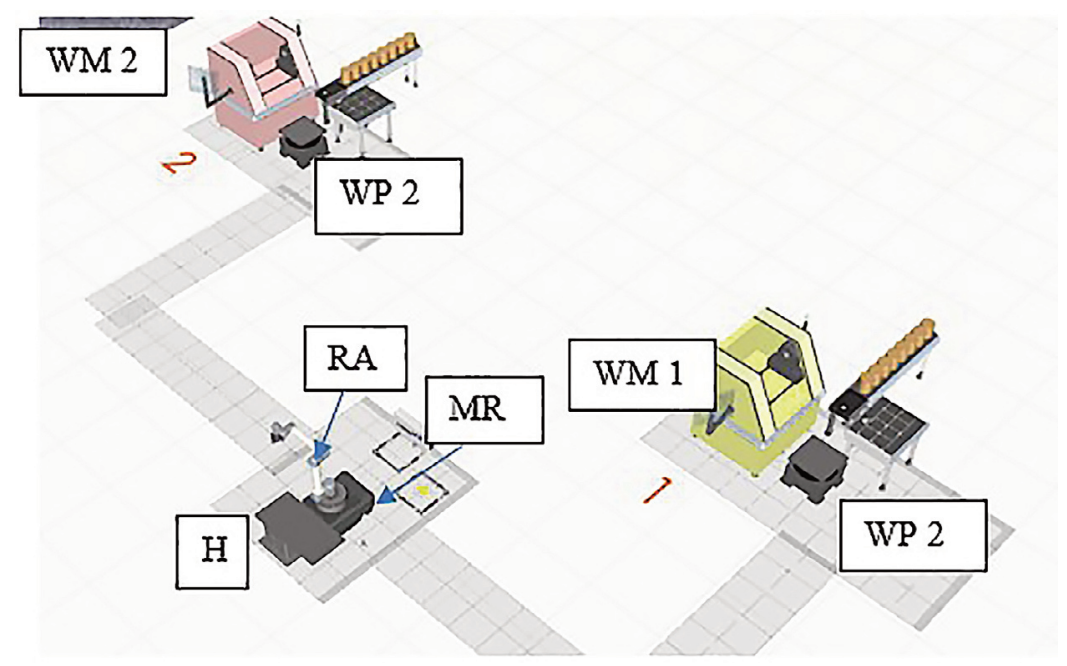

Fig. 2. Robot arm (RA) moved by mobile robot (MR) between working positions (WP 1, WP 2). WM 1 and WM 2 are working machines, $\mathrm{H}$ is the home position for mobile robot.

to the workplace using machine vision. Once the position had been detected, the robot arm connected itself to the communication network by a special plug. The start signal was transmitted to the Manufacturing Execution System (MES), which in return sent the correct command to start the correct program inside the robot arm controller. Communication between the MES and the RA and the MR was made via WiFi (IEEE 802.11). At the end of the work process, the robot disconnected itself from the communication network, transmitted a signal that the work was finished and waited to be transported to the next task. The whole process took place without human interaction.

Two different use cases were analysed. Use case A is a common way of how the robot arm is utilized by SMEs. Use case B is a new method proposed by us, where the robot arm is moving constantly between WPs to execute tasks and reduce downtime.

\subsection{Use case A}

- Two workplaces, one robot arm, one mobile robot.

- Lot size of 8 pieces (parts that are produced with the machines, see Table 1).

- Operation time for Machine 1 is 3 minutes per part and for Machine 2 it is 5 minutes per part.

- All parts are produced first in Working Machine 1 (WM 1) and then in Working Machine 2 (WM 2). The robot stays with Machine 1 until the parts are ready and then moves to Machine 2 and stays there until all the parts are completed.

- The mobile robot leaves after it has moved the robot arm.

Table 1. Input data for mathematical analysis

\begin{tabular}{lcc}
\hline \multicolumn{1}{c|}{ Name } & Value & Formula unit \\
\hline Lot size & 8 pieces & $\mathrm{x}_{1}$ \\
Time to insert a part into WM with RA & $15 \mathrm{~s}$ & $\mathrm{x}_{2}$ \\
Time to take out a part from WM with RA & $20 \mathrm{~s}$ & $\mathrm{x}_{3}$ \\
RA positioning time & $30 \mathrm{~s}$ & $\mathrm{X}_{4}$ \\
MR movement time from (H) to WM 1 & $20 \mathrm{~s}$ & $\mathrm{x}_{5}$ \\
MR movement time from (H) to WM 2 & $20 \mathrm{~s}$ & $\mathrm{X}_{6}$ \\
MR movement time from WM 1 to WM 2 & $50 \mathrm{~s}$ & $\mathrm{X}_{7}$ \\
Working time of WM 1 & $180 \mathrm{~s}$ & $\mathrm{X}_{8}$ \\
Working time of WM 2 & $300 \mathrm{~s}$ & $\mathrm{X}_{9}$
\end{tabular}




\subsection{Use case $B$}

- Two workplaces, one robot arm, one mobile robot.

- Lot size of 8 pieces (parts that are produced with the machines).

- Operation time for Machine 1 is 3 minutes per part and for Machine 2 it is 5 minutes per part.

- Machines 1 and 2 are working simultaneously. The robot arm is moving constantly between Machine 1 and Machine 2.

- The mobile robot leaves after it has moved the robot arm.

The data collected from the use cases include working hours of the mobile robot, robot arm and working machines. In parallel, a mathematical calculation was performed with parameters (given in Table 1) for the use cases and compared with the simulation results.

\section{SIMULATION DATA ANALYSIS}

The set of data obtained from the Visual Components analysis is presented graphically in Figs 3-4. Comparison of the WM 1 and WM 2 utilization in use cases A and B shows that the utilization for use case A is very low but very high for use case B, close to $90 \%$. At the same time, a large decrease in production time can be seen. The production time for use case A is 68 minutes and for use case B it is 44 minutes, i.e. the production time is reduced by approx. $35 \%$.

As regards use case A, the determination of the use of a mobile robot is very low. The average utilization of the MR is 3.8\%. For use case B the utilization is much higher, $37.5 \%$, being roughly 10 times higher. The robot arm utilization time is given as the sum of both work positions (WP 1 and WP 2). The utilization for use case A is low, $3.7 \%$. This is due to the fact that the RA does not work during the working hours of the WM. In use case B the RA is constantly moved between the two WPs and the RA utilization is increasing almost 2 times. The average utilization of the RA for use case B is $6 \%$.

In addition to the Visual Components simulation, the results were also analysed mathematically. In regard to different use cases, the operating time and idle time of the devices were calculated, and calculations of the operating time and utilization were made on the basis of them (see Tables 2-3).

$$
\begin{gathered}
R A_{w h . A}=\frac{\left(x_{2}+x_{3}\right) \times x_{1}+\left(x_{4} \times 2\right)+\left(x_{2}+x_{3}\right) \times x_{1}+\left(x_{4} \times 2\right)}{3600}, \\
R A_{w h . B}=\frac{\left(x_{4} \times x_{1} \times 2+x_{2} \times x_{2}+x_{3} \times x_{1}\right)+\left(x_{4} \times x_{2} \times 2+x_{2} \times x_{1}+x_{3} \times x_{2}\right)}{3600}, \\
M R_{w h . A}=\frac{\left(x_{5} \times 3+x_{7}+x_{6} \times 3\right)}{3600}, \\
M R_{\text {wh. } B}=\frac{\left(x_{5}+\left(x_{5}+x_{7}+x_{6}\right) \times\left(x_{2}-1\right)+\left(x_{6}+x_{7}+x_{5}\right) \times x_{1}\right.}{3600}, \\
\text { Total process time }=\frac{\left(x_{8} \times x_{2}+x_{9} \times x_{1}\right)+\left(x_{5}+x_{4} \times 2+x_{7}+x_{4} \times 2+x_{6}\right)+\left(\left(x_{2}+x_{3}\right) \times x_{1} \times x_{2}\right)}{3600}, \\
\text { Total process time } e_{B}=\frac{\left(x_{9} \times x_{1}\right)+\left(\left(x_{4}+x_{2}+x_{3}+x_{4}\right) \times x_{1} \times 2\right)}{3600} .
\end{gathered}
$$

Average utilization time for the RA and the MR is calculated as follows:

$$
R A_{u t . x}=\frac{R A_{\text {wh. } .} \times 100}{\text { Total process time }_{x}} \quad M R_{\text {ut. } x}=\frac{M R_{\text {wh. } . x} \times 100}{\text { Total process time }_{x}} .
$$


(a)

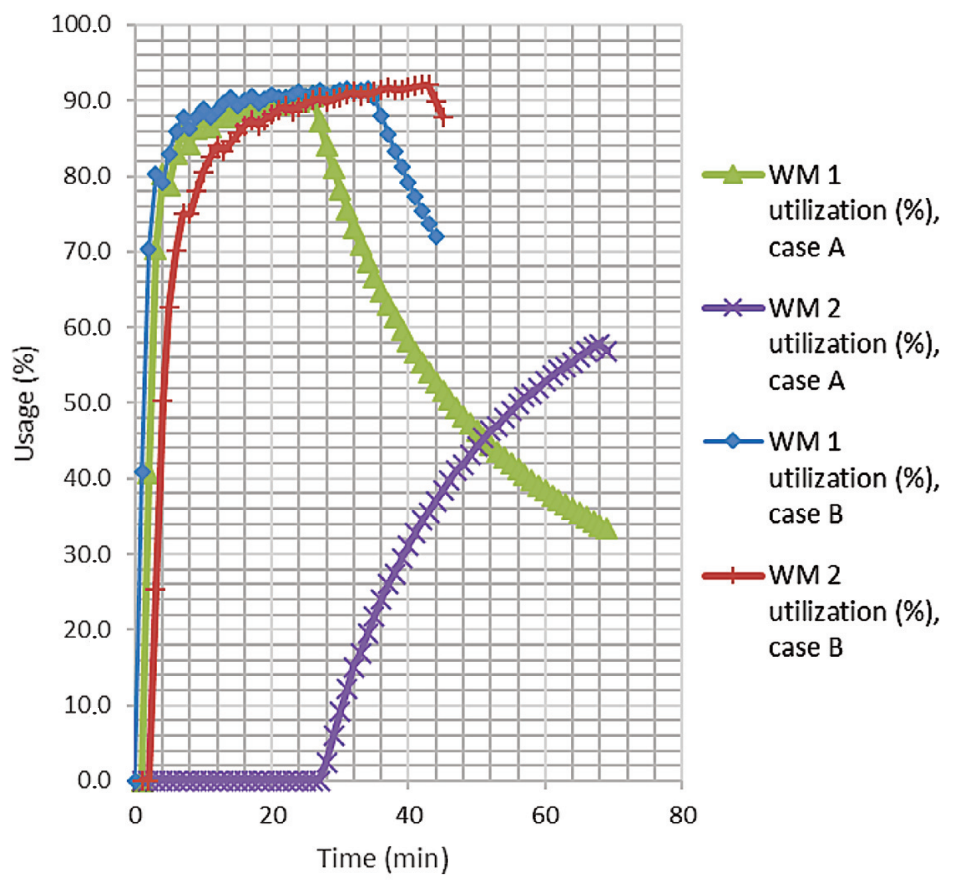

(b)

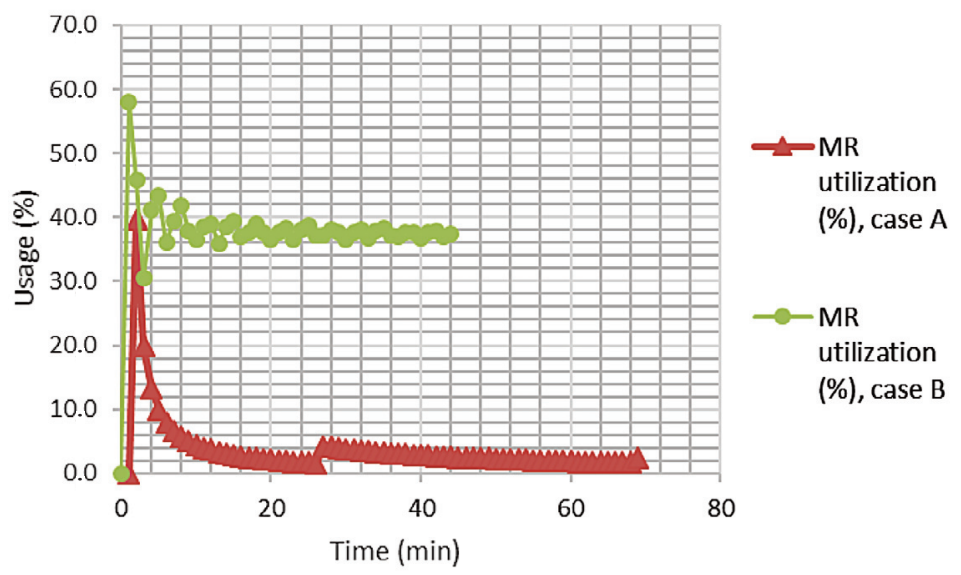

Fig. 3. Working machine utilization (a) and mobile robot utilization (b).

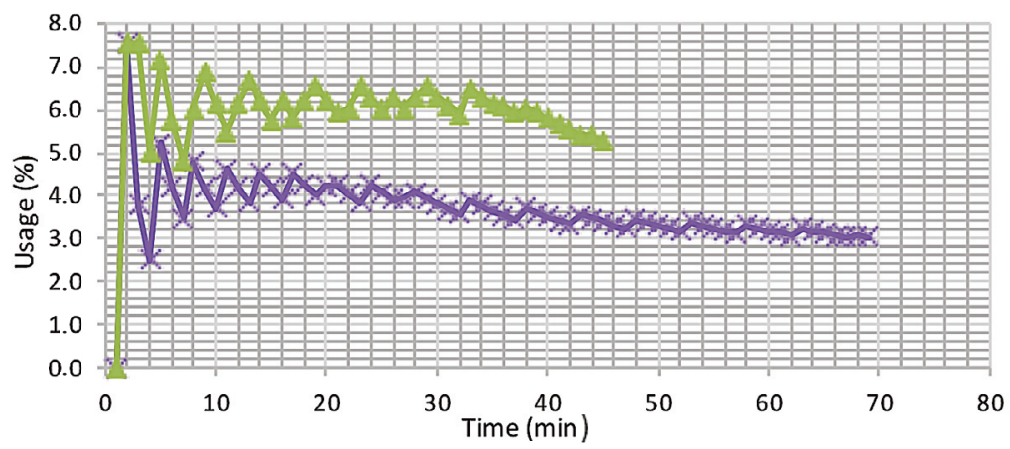

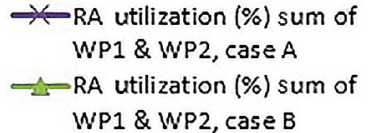

WP1 \& WP2, case B

Fig. 4. Robot arm utilization. 
Table 2. Working and idle hours of RA and MR

\begin{tabular}{l|c|c|c|c}
\hline Use case (x) & $R A_{w h}$ & $M R_{w h}$ & $R A_{i h}$ & $M R_{i h}$ \\
\hline A & 0.19 & 0.05 & 1.09 & 1.07 \\
B & 0.42 & 0.38 & 0.23 & 0.78 \\
$\begin{array}{l}\text { wh-working hours. } \\
\text { ih-idle hours. }\end{array}$
\end{tabular}

Table 3. Utilization of RA and MR

\begin{tabular}{c|c|c|c}
\hline Use case (x) & $R A_{u t}$ & $M R_{u t}$ & $\begin{array}{c}\text { Total process } \\
\text { time }\end{array}$ \\
\hline A & $14.8 \%$ & $3.7 \%$ & 1.28 \\
B & $38.8 \%$ & $34.9 \%$ & 1.09 \\
\multicolumn{2}{c}{ ut - utilization, working time calculated from total time (\%). }
\end{tabular}

There are some differences between the simulation and the mathematical computer because it is not possible to enter certain time parameters for the operation of the RA in the visualization program. A mathematical model provides more accurate results than a simulation. Input data units are in seconds. Output values are given in hours.

The results of the simulation and mathematical calculation are different. The reason is that the simulation software does not have the option for adding additional time for RA adjustment before starting work with the WM. The mathematical calculation of use case B compared with use case A indicates that the time required for production decreases by about $20 \%$ and the use time of the RA and MR devices increases significantly by about 2 times.

By changing the input parameters of the process, the performance indicators also change. Extending the working time of the WM significantly reduces the total production time for use case B compared with use case A. By increasing the distance between the working machines, i.e. by increasing the travel path of the $\mathrm{MR}$, the production time as well as the utilization rate of the RA and the MR decrease for use case B.

\section{CONCLUSIONS}

The use of industrial robots in SMEs has been modest so far, one of the reasons being the lack of work for the robot in one particular location. Moving the robotic arm between working positions would significantly increase its usability and increase the rate of use of the device itself. This article has compared two different ways of using a robot, the second of which (use case B) allows the robot arm to move autonomously between different workstations on the factory site with the help of a mobile robot. Autonomous movement of the robot arm between different work positions significantly increases the usability of the robot and increases production efficiency. As a result, a virtual production line was added to semi-industrial Industry 4.0 Lab, allowing better pre-planning and faster reconfiguration without stopping the real time production.

\section{ACKNOWLEDGEMENTS}

The publication costs of this article were covered by the Estonian Academy of Sciences and Tallinn University of Technology.

\section{REFERENCES}

1. Kangru, T., Riives, J., Mahmood, K. and Otto, T. Suitability analysis of using industrial robots in manufacturing. Proc. Est. Acad. Sci., 2019, 68(4), 383-388.

2. Barosz, P., Gołda, G. and Kampa, A. Efficiency analysis of manufacturing line with industrial robots and human operators. Appl. Sci., 2020, 10(8), 2862.

3. Unger, H., Markert, T. and Müller, E. Evaluation of use cases of autonomous mobile robots in factory environments. Procedia Manuf., 2018, 17, 254-261.

4. Vaher, K., Otto, T. and Riives, J. Positioning error correction of autonomously movable robot arm. J. Mach. Eng., 2020, 20(4), 152-160. 
5. Mahmood, K., Lanz, M., Toivonen, V. and Otto, T. A performance evaluation concept for production systems in an SME network. Procedia CIRP, 2018, 72, 603-608.

6. Kangru, T., Riives, J., Otto, T., Pohlak, M. and Mahmood, K. Intelligent decision making approach for performance evaluation of a robot-based manufacturing cell. In Proceedings of the ASME 2018 International Mechanical Engineering Congress and Exposition: IMECE2018, Pittsburgh, PA, USA, November 9-15, 2018. ASME, IMECE2018-86666.

7. Lima, F., de Carvalho, C. N., Acardi, M. B. S., dos Santos, E. G., de Miranda, G. B., Maia, R. F. and Massote, A. A. Digital manufacturing tools in the simulation of collaborative robots: towards Industry 4.0. Braz. J. Oper. Prod. Manag., 2019, 16(2), 261-280.

8. Vaher, K., Kangru, T., Otto, T. and Riives, J. The mobility of robotised work cells in manufacturing. In Proceedings of the 30th International DAAAM Symposium "Intelligent Manufacturing \& Automation”, Zadar, Croatia, October 23-26, 2019. DAAAM International, Vienna, 1049-1055.

9. Kousi, N., Michalos, G., Aivaliotis, S. and Makris, S. An outlook on future assembly systems introducing robotic mobile dual arm workers. Procedia CIRP, 2018, 72, 33-38.

10. Nielsen, I. E., Dang, Q. V., Bocewicz, G. and Banaszak, Z. A methodology for implementation of mobile robot in adaptive manufacturing environments. J. Intell. Manuf., 2017, 28(5), 1171-1188.

\section{Autonoomselt liikuva robotkäe simulatsioonipõhine teostatavusanalüüs}

\section{Kristo Vaher, Kashif Mahmood, Tauno Otto ja Jüri Riives}

Tööstusrobotite kasutamine tootmises kasvab kiiresti. Tööstusrobotite laialdast kasutamist ja uute tootmistehnoloogiate kasutuselevõttu edendavad enamasti suured tööstusettevõtted. See on tingitud tootmismahu iseärasusest, kuna robotitel on tootmisprotsessis ühes kindlas positsioonis palju sama tüüpi tööd. Väiksemates ettevõtetes, kus robotitel pole ühes töökohas sageli piisavalt töökoormust, pole robotiseerimisprotsess olnud nii edukas. Väikese ja keskmise suurusega ettevõtted (VKE-d) vajavad lahendust, kus robotit saab ühest töökohast teise viia, et ressursse nagu robotkäpp tõhusalt kasutada. Selle artikli eesmärk on analüüsida robotkäe (koostööroboti) kasutamise otstarbekust, teenindada rohkem kui üht tootmisseadet. Tootmismasinad asuvad teatud kaugusel ja robotkäe liikumine masinate vahel toimub autonoomse mobiilroboti abil. Lisaks kasutati kahe erineva stsenaariumi läbiviimiseks ja analüüsimiseks simulatsiooni ja 3D-visualiseerimist. Uurimuses võrreldakse erinevate masinate kasutamismäära erinevates situatsioonides. 